5. Zueva L.P., Aslanov B.I., Akimkin V.G. A modern view of the role of bacteriophages in the evolution of hospital strains and the prevention of infections associated with medical care. Zhurnal mikrobiologii, epidemiologii and immunobiologii. 2014; (3): 100-7. (in Russian)

6. WHO. Antimicrobial resistance: https://www.who.int/news-room/factsheets/detail/

7. Topchiy N.V., Toporkov A.S. Bacteriophages in the treatment of acute intestinal infections. Meditsinskiy sovet. 2015; (8): 74-81. (in Russian)

8. Sulakvelidze, A. Bacteriophage therapy (minireview) / A.Sulakvelidze, Z.Alavidze, J.G.Vorris // Antimicrob Agents Chemother. - 2001. - Vol.45(3).

DOI https://doi.org/10.30525/978-9934-26-075-9-35

\title{
ВПЛИВ УНІТІОЛУ НА ФУНКЦІЮ НИРОК У МОЛОДИХ СТАТЕВОНЕЗРІЛИХ ТВАРИН
}

\author{
Гордієнко В. В. \\ кандидат медичних наук, \\ доиент кафедри фізіології імені Я. Д. Кіриенблата \\ Буковинський державний медичний університет \\ Косуба Р. Б. \\ доктор медичних наук, \\ професорка кафедри фармакології \\ Буковинський державний медичний університет \\ Гордіснко І. К. \\ викладачка фармакологї та медичної рецептури \\ Чернівеиький медичний фаховий коледж, \\ Буковинський державний медичний університет \\ м. Чернівиі, Україна
}

Унітіол (димеркаптопропансульфонат натрію) - антидотний препарат при гострих і органічних отруєннях тіоловими отрутами [1, с. 25-27]. Завдяки хімічній будові унітіол позитивно впливає на антиоксидантну систему захисту, захищає тіолові групи білків, пришвидшує реакції перекисного окиснення, посилює ефект глутатіону [2, с. 72]. Препарат застосовують для лікування інтоксикацій, спричинених отрутами, лікарськими препаратами, а також для зменшення побічних ефектів 138 
фармакотерапії [3, с. 429-430; 4, с. 46]. Однак, ще не достатньо з'ясовані особливості впливу препарату на функцію нирок у молодому віці, зокрема за різних режимів застосування.

Метою дослідження стало вивчення впливу унітіолу на функцію нирок молодих статевонезрілих тварин за одноразового та повторних уведень.

Робота виконана на статевонезрілих щурах-самцях масою 95,0 $\pm 8,5$ г. Функцію нирок досліджували після одноразового та тривалого $(10,20$, 30 діб) уведень розчину унітіолу в дозі 50 мг/кг на тлі водного діурезу. Через 30 хв після ін'єкції унітіолу дослідним та контрольним тваринам робили водне навантаження (5\% від маси тіла тварин теплої питної води per os через зонд), після чого поміщали в індивідуальні клітки і збирали сечу впродовж 2 год. У сечі визначали концентрацію йонів натрію, калію, вміст білку, креатиніну, титрованих кислот, аміаку, протонів водню та $\mathrm{pH}$.

Проведеними дослідженнями встановлено, що через 2,5 год. після одноразової ін'єкції унітіолу у тварин діурез не змінився, концентрація йонів натрію в сечі і натрійурез зросли у 1,7 рази. Відповідно зменшилася концентрація йонів калію та калійурез - в 1,7 та 1,6 рази, що сприяло підвищенню $\mathrm{Na}^{+} / \mathrm{K}^{+}$коефіцієнту в сечі в 2,5 рази, порівняно 3 контролем, що відрізняється від реакції нирок у статевозрілих щурів за аналогічних умов експерименту [5, с. 47]. Концентрація, екскреція білку та креатиніну з сечею не змінилися. Не зазнали суттєвих змін також показники кислотнорегулювальної функції нирок.

Однак, на тлі 10-добового щоденного введення унітіолу концентрація йонів натрію в сечі різко зменшилася - в 1,9 рази порівняно з контролем i в 3,2 рази порівняно 3 реакцією тварин на одноразову ін'єкцію препарату. Після 20- та 30-добових уведень унітіолу концентрація йонів натрію в сечі продовжувала знижуватися в 2,9 та 2,7 рази, відповідно. Натрійурез на 10-ту добу ін'єкції знизився, порівняно $з$ одноразовим уведенням майже у 4 рази і на такому рівні утримувався на 20-ту та 30 -ту доби введення препарату. Концентрація та екскреція йонів калію при тривалому 10-30-добовому введенні утримувалась на рівні контрольних показників. $\mathrm{Na}^{+} / \mathrm{K}^{+}$коефіцієнт в сечі на $10-30$-у доби введення препарату став у 1,7-2,5 рази меншим вихідного рівня. Концентрація ендогенного креатиніну в сечі суттєво не змінювалася впродовж усього терміну спостереження, що свідчить про відсутність впливу унітіолу на процеси клубочкової ультрафільтрації.

Після 10-добового введення унітіолу концентрація білку в сечі зменшилася в 2,2 рази і утримувалася на такому рівні після 20-ти 
та 30-ти ін'єкцій препарату. Екскреція титрованих кислот і аміаку після 10-добового введення зменшилася в 1,8 разу, після 20-ої доби зросла відповідно, в 1,4-1,5 рази, а на 30-ту добу - не відрізнялася від показників контрольних тварин, що суттєво не вплинуло на рН сечі.

Отже, тривале введення статевонезрілим щурам унітіолу, суттєво не впливаючи на діурез, секрецію, йонів калію, показники кислотнорегулювальної функції нирок, на відміну від одноразового введення, помітно зменшує натрійурез та втрати організмом білка 3 сечею, що обгрунтовує доцільність застосування унітіолу за умов металотоксикозу, навпаки, при якому відбувається втрата організмом йонів натрію і білку як ознаки нефротоксичності металів [6, с. 131-132].

\section{Література:}

1. Трахтенберг И.М., Шейман Б.С., Проданчук Н.Г. Актуальные аспекты проблемы антидотной терапии в Украине. Наука $і$ практика. 2014. 1(2). С. 22-37.

2. Губський Ю.І., Задоріна О.В., Ерстенюк Г.М., Осинська Л.Ф. Вплив унітіолу на окислювальну модифікацію білків плазми крові та процеси пероксидації ліпідів мембран гепатоцитів щурів за умов інтоксикації хлоридом кадмію. Современные проблемы токсикологии. 2008. №2. C. 70-73.

3. Апихтіна О.Л. Отруєння та особливості застосування антидотів. ВкКн. Трахтенберг І.М., редактор. Лікарська токсикологія. Доклінічні дослідження. Київ: Авіцена: 2019. С. 411-477.

4. Каминский Р.Ф. Изменения в миокарде при хроническом воздействии хлорида ртути и использование унитиола и кварцетина в качестве кардиопротекторов. Украӥнський журнал з проблем медицини nраųi. 2010. № 2 (22). С. 43-47.

5. Косуба Р.Б., Гордієнко В.В., Перепелиця О.О. Вплив унітіолу на функцію нирок. Клінічна та експериментальна патологія. 2019. № 18 (4). С. 43-48.

6. Бойчук Т.М., Гордієнко В.В., Роговой Ю.С. Хроноритми нирок: віковий аспект за умов металотоксикозу. Чернівці: БДМУ. 2016. 177 с. 